\title{
DSM-5: Call for Commentaries on Gender Dysphoria, Sexual Dysfunctions, and Paraphilic Disorders
}

\author{
Kenneth J. Zucker
}

Published online: 25 June 2013

(c) Springer Science+Business Media New York 2013

On May 18, 2013, at the annual meeting of the American Psychiatric Association in San Francisco, the fifth edition of the Diagnostic and Statistical Manual of Mental Disorders (American Psychiatric Association, 2013) was, with intense anticipation, released.

When I arrived the day earlier, I immediately encountered three men protesting peacefully on the sidewalk outside of my hotel: One sign read "Equal Rights for Men! End Forced Circumcision." Another read "Intact Genitals Are a Human Right." I wasn't sure what this had to do with the DSM-5. Turns out, it was a different protest for a different meeting. False alarm.

As hoards of psychiatrists wandered in and about the Moscone Center holding their newly-purchased purple-colored copies of DSM-5 — all 947 pages of it —one could not help but notice the curious juxtaposition with what seemed to my eye a lot of homeless people with psychotic symptoms also wandering around the neighborhood. As usual, the scientologists were out on the street in force although I did not see Tom Cruise. I respectfully told one protester that she needed to go Arabic from Roman (DSM-5, not DSM-V). She thanked me for the tip.

Since the DSM-5 Task Force was formally announced in April 2008, a tremendous amount of effort was put into the final product: literature reviews, secondary data analyses, field trials, face-to-face meetings, conference calls, and, in the era of the Internet, thousands upon thousands of e-mails. In addition, the Task Force received input in the form of public commentaries, feedback from advisors to the Workgroups, and internal review panels. In this issue, the Gender Identity Disorders subworkgroup has reproduced its Memo Outlining Evidence for Change

\section{K. J. Zucker ( $\square)$}

Gender Identity Service, Child, Youth, and Family Services, Underserved Populations Program, Centre for Addiction and Mental Health, 80 Workman Way, Toronto, ON M6J 1H4, Canada e-mail: Ken.Zucker@camh.ca for Gender Identity Disorder (Zucker et al., 2013), which it had submitted to two internal advisory committees to the DSM-5 Task Force: the Scientific Review Committee and the Clinical and Public Health Committee. By publishing it in Archives, the argumentation of the subworkgroup is available for perusal by anyone who wants to read it.

I chaired the Sexual and Gender Identity Disorders Workgroup. It consisted of three subworkgroups: Gender Identity Disorders, Sexual Dysfunctions, and the Paraphilias. Table 1 lists the members of these three subworkgroups. Our Workgroup published its literature reviews in 2010 in the Archives of Sexual Behavior and in the Journal of Sexual Medicine (Binik, 2010a, b; Blanchard, 2010a, b; Brotto, 2010a, b, c; CohenKettenis \& Pfäfflin, 2010; Drescher, 2010; Graham, 2010a, b; Kafka, 2010a, b, c; Krueger, 2010a, b; Långström, 2010; MeyerBahlburg, 2010; Segraves, 2010a, b, c; Zucker, 2010). There were also contributions from advisors to the Workgroup (Hanson, 2010; Hucker, 2011; Knight, 2010; Quinsey, 2010; Stern, 2010; Thornton, 2010). The diagnostic proposals and rationales (in various iterations) were also posted on the dsm5.org website of the American Psychiatric Association.

Since 2010, various articles, commentaries, one consumer survey, and Letters-to-the Editor weighed in on the literature reviews and proposals by the Workgroup or had more general things to say (e.g., Angel, 2010; Balon, 2010, 2012, 2013; Balon \& Wise, 2011; Beier et al., 2013; Berlin, 2011; Binik, Brotto, Graham, \& Segraves, 2010; Blanchard, 2010c, d, 2011a, b, 2012; Brotto, Graham, Binik, Segraves, \& Zucker, 2011; Cantor, 2012a, b; De Block \& Adriaens, 2013; DeRogatis, Clayton, Rosen, Sand, \& Pyke, 2011; DeRogatis et al., 2010a, b; Drescher, 2013; Drescher, Cohen-Kettenis, \& Winter, 2012; Eliason, 2010¹ ; Fabian, 2011; Fedoroff, 2011; First, 2010, 2011; Frances \& First, 2011a, b; Frances \& Wollert, 2012; Franklin,

\footnotetext{
${ }^{1}$ My favorite reference of them all.
} 
Table 1 Members of the DSM-5 Workgroup on Sexual and Gender Identity Disorders (Chair: Kenneth J. Zucker, Ph.D.)

\begin{tabular}{|c|c|}
\hline Subworkgroup & Members \\
\hline Gender Identity Disorders & $\begin{array}{l}\text { Peggy T. Cohen-Kettenis, Ph.D. (Chair) } \\
\text { Jack Drescher, M.D. } \\
\text { Heino F. L. Meyer-Bahlburg, Dr. rer. nat. } \\
\text { Friedemann Pfäfflin, M.D. }\end{array}$ \\
\hline Sexual Dysfunctions & $\begin{array}{l}\text { R. Taylor Segraves, M.D., Ph.D. (Chair) } \\
\text { Yitzchak M. Binik, Ph.D. } \\
\text { Lori A. Brotto, Ph.D. } \\
\text { Cynthia A. Graham, Ph.D. }\end{array}$ \\
\hline Paraphilias & $\begin{array}{l}\text { Ray Blanchard, Ph.D. (Chair) } \\
\text { Martin P. Kafka, M.D. } \\
\text { Richard B. Krueger, M.D. } \\
\text { Nikolas Langstrom, M.D., Ph.D. }\end{array}$ \\
\hline
\end{tabular}

2010a, b, 2011; Garcia \& Thibaut, 2010; Giordano, 2011; Good \& Burstein, 2012; Green, 2010; Halpern, 2011; Hames \& Blanchard, 2012, 2013; Hendrickx, Gijs, \& Enzlin, 2013; Hinderliter, 2010, 2011; Janssen, 2013; Johnson \& Wassersug, 2010; Kafka, 2010d; Kafka \& Krueger, 2011a, b; Kim et al., 2010; Koh, 2012; Kramer, 2011; Krueger, 2011; Krueger \& Kaplan, 2012; Lawrence, 2010a, b, 2011; Levine, 2010a, b; Malón, 2012; Marshall \& Briken, 2010; Marvin, 2010; Meyer-Bahlburg, 2011; Moser, 2010, 2011a, b; O’Donohue, 2010; Pfäfflin, 2011; Prentky \& Barbaree, 2011; Quinsey, 2012; Reid et al., 2012; Rind, 2013; Rind \& Yuill, 2012; Ryniker, 2012; Seto, 2010, 2012; Shindel \& Moser, 2011; Singy, 2010; Stern, 2011; Taborda \& MichalskiJaeger, 2012; Tucker \& Brakel, 2012; Vale et al., 2010; Vance et al., 2010; Wakefield, 2011; Walters, Knight, \& Langstrom, 2011; Winters, 2010; Winters, Christoff, \& Gorzalka, 2010; Wölfle, 2010; Wollert, 2011; Wollert \& Cramer, 2011; Wright, 2010; Wylie, Ralph, Levin, Corona, \& Perelman, 2010; Zonana, 2011; see also Ault \& Brzuzy, 2009; Balon, 2008; Balon, Segraves, \& Clayton, 2007; Brotto, Bitzer, Laan, Leiblum, \& Luria, 2010; DeRogatis et al., 2012; First \& Frances, 2008; First \& Halon, 2008; Gert \& Culver, 2009; Giles \& McCabe, 2009; Laan \& Both, 2011; Mitchell \& Graham, 2008; Neutze, Grundmann, Scherner, \& Beier, 2012; Rellini \& Clifton, 2011; Segraves, Balon, \& Clayton, 2007), including one entire issue of the International Journal of Transgenderism in 2010 and then several additional articles in
Table 2 From DSM-IV-TR to DSM-5: Gender Dysphoria, Sexual Dysfunctions, and Paraphilic Disorders
For the Sexual Dysfunctions and the Paraphilic Disorders, the diagnoses are listed in the order that they appear in the DSM-5

\begin{tabular}{|c|c|}
\hline DSM-IV-TR diagnosis & DSM-5 diagnosis \\
\hline Gender Identity Disorder & Gender Dysphoria \\
\hline Gender Identity Disorder Not Otherwise Specified & $\begin{array}{l}\text { Other Specified Gender Dysphoria } \\
\text { Unspecified Gender Dysphoria }\end{array}$ \\
\hline Male Orgasmic Disorder & Delayed Ejaculation \\
\hline Male Erectile Disorder & Erectile Disorder \\
\hline Female Orgasmic Disorder & Female Orgasmic Disorder \\
\hline Hypoactive Sexual Desire Disorder & Female Sexual Interest/Arousal Disorder \\
\hline \multicolumn{2}{|l|}{ Female Sexual Arousal Disorder } \\
\hline Dyspareunia & Genito-Pelvic Pain/Penetration Disorder \\
\hline \multicolumn{2}{|l|}{ Vaginismus } \\
\hline Hypoactive Sexual Desire Disorder & Male Hypoactive Sexual Desire Disorder \\
\hline Premature Ejaculation & Premature (Early) Ejaculation \\
\hline Sexual Aversion Disorder & Deleted \\
\hline $\begin{array}{l}\text { Sexual Dysfunction Due to a General } \\
\text { Medical Condition }\end{array}$ & Substance/Medication-Induced Sexual Dysfunction \\
\hline \multicolumn{2}{|l|}{ Substance-Induced Sexual Dysfunction } \\
\hline Sexual Dysfunction Not Otherwise Specified & $\begin{array}{l}\text { Other Specified Sexual Dysfunction } \\
\text { Unspecified Sexual Dysfunction }\end{array}$ \\
\hline Voyeurism & Voyeuristic Disorder \\
\hline Exhibitionism & Exhibitionistic Disorder \\
\hline Frotteurism & Frotteuristic Disorder \\
\hline Sexual Masochism & Sexual Masochism Disorder \\
\hline Sexual Sadism & Sexual Sadism Disorder \\
\hline Pedophilia & Pedophilic Disorder \\
\hline Fetishism & Fetishistic Disorder \\
\hline Transvestic Fetishism & Transvestic Disorder \\
\hline Paraphilia Not Otherwise Specified & $\begin{array}{l}\text { Other Specified Paraphilic Disorder } \\
\text { Unspecified Paraphilic Disorder }\end{array}$ \\
\hline
\end{tabular}


2011 (Bouman, Bauer, Richards, \& Coleman, 2010; Corneil, Eisfeld, \& Botzer, 2010; De Cuypere, Knudson, \& Bockting, 2010; Ehrbar, 2010; Fraser, Karasic, Meyer, \& Wylie, 2010; Green, McGowan, Lev, Wallbank, \& Whittle, 2011; Haraldsen, Ehrbar, Gorton, \& Menvielle, 2010; Knudson, De Cuypere, \& Bockting, 2010a, b, c, 2011a, b; Rachlin, Dhejne, \& Brown, 2010; RichterAppelt \& Sandberg, 2010). Of course, the Internet was not short of various opinions (if one does not have a life, one could read away forever).

Table 2 shows the final diagnostic categories for the DSM-5. Unlike the DSM-IV, in which the Sexual and Gender Identity Disorders constituted one stand-alone chapter, the DSM-5 has three separate chapters for Gender Dysphoria (the diagnostic name change from Gender Identity Disorder), Sexual Dysfunctions, and Paraphilic Disorders (the diagnostic name change from Paraphilias). The Workgroup had proposed for Section III (Conditions for Further Study) three additional diagnoses for further study: Body Integrity Identity Disorder, Hypersexual Disorder, and Paraphilic Coercive Disorder. All three proposals were not approved for inclusion in Section III by the Board of Trustees (BOT) of the American Psychiatric Association. The BOT also did not approve the proposed change to Criterion A for Pedophilic Disorder and the inclusion of specifiers pertaining to Tanner stages (Tanner Stage 1, Tanner Stages 2-3, and a combined type). Thus, in DSM-5, the diagnostic criteria for Pedophilic Disorder remain unchanged from DSM-IV-TR. In this issue, Blanchard (2013) has articulated his disagreement with this decision, a position that I am in full agreement with (Zucker, 2013).

\section{Call for Commentaries}

Now that the verdict is in, the Archives will consider commentaries on the DSM-5 work product. Commentaries might focus on conceptual issues, empirical issues, sociopolitical issues, or suggestions for further research in the post-DSM-5 era. It would be best for a particular commentary to focus on one particular issue. It should be no longer than 10 double-spaced pages, including references prepared using APA style. It should be submitted directly to the Editor as a WORD document at Ken.Zucker@ camh.ca. Please do not submit it via the Journal's web portal at Editorial Manager.

\section{References}

American Psychiatric Association. (2013). Diagnostic and statisticalmanual of mental disorders (5th ed.). Arlington, VA: Author.

Angel, K. (2010). The history of 'female sexual dysfunction' as a mental disorder in the 20th century. Current Opinion in Psychiatry, 23, 536-541.

Ault, A., \& Brzuzy, S. (2009). Removing gender identity disorder from the Diagnostic and Statistical Manual of Mental Disorders: A call for action. Social Work, 54, 187-189.
Balon, R. (2008). The DSM criteria of sexual dysfunction: Need for a change. Journal of Sex and Marital Therapy, 34, 186-197.

Balon, R. (2010). Proposal to introduce Adjustment Disorder with disturbed sexual functioning into the revised classifications of DSM and ICD. Journal of Sex and Marital Therapy, 36, 1-5.

Balon, R. (2012). The debate about Paraphilic Coercive Disorder is mostly ideological and going nowhere [Letter to the Editor]. Archives of Sexual Behavior, 41, 535-536.

Balon, R. (2013). Controversies in the diagnosis and treatment of paraphilias. Journal of Sex and Marital Therapy, 39, 7-20.

Balon, R., Segraves, R. T., \& Clayton, A. (2007). Issues for DSM-V: Sexual dysfunction, disorder, or variation along normal distribution: Toward rethinking DSM criteria of sexual dysfunctions. American Journal of Psychiatry, 164, 198-200.

Balon, R., \& Wise, T. N. (2011). Update on diagnoses of sexual dysfunctions: Controversies surrounding the proposed revisions of existing diagnostic entities and proposed new diagnoses. Advances in Psychosomatic Medicine, 31, 1-15.

Beier, K. M., Amelung, T., Kuhle, L., Grundmann, D., Schemer, G., \& Neutze, J. (2013). Hebephilie als sexuelle Störung [Hebephilia as a sexual disorder]. Fortschritte der Neurologie Psychiatrie, 81, 128137.

Berlin, F. S. (2011). Commentary on pedophilia diagnostic criteria in DSM5. Journal of the American Academy of Psychiatry and the Law, 39, 242 244.

Binik, Y.M.(2010a). The DSM diagnostic criteria for Dyspareunia.Archives of Sexual Behavior, 39, 278-291.

Binik, Y. M. (2010b). The DSM diagnostic criteria for Vaginismus. Archives of Sexual Behavior, 39, 292-303.

Binik, Y. M., Brotto, L. A., Graham, C. A., \& Segraves, R. T. (2010). Response of the DSM-5 Sexual Dysfunctions Subworkgroup to commentaries published in the Journal of Sexual Medicine. Journal of Sexual Medicine, 7, 2382-2387.

Blanchard, R. (2010a). The DSM diagnostic criteria for Pedophilia. Archives of Sexual Behavior, 39, 304-316.

Blanchard, R. (2010b). The DSM diagnostic criteria for Transvestic Fetishism. Archives of Sexual Behavior, 39, 363-372.

Blanchard, R. (2010c). The specificity of victim count as a diagnostic indicator of pedohebephilia [Letter to the Editor]. Archives of Sexual Behavior, 39, 1245-1252.

Blanchard, R. (2010d). The fertility of hebephiles and the adaptationist argument against including hebephilia in DSM-5 [Letter to the Editor]. Archives of Sexual Behavior, 39, 817-818.

Blanchard, R. (2011a). A brief history of field trials of the DSM diagnostic criteria for paraphilias [Letter to the Editor]. Archives of Sexual Behavior, 40, 861-862.

Blanchard, R. (2011b). Misdiagnoses of pedohebephilia using victim count: A reply to Wollert and Cramer (2011) [Letter to the Editor]. Archives of Sexual Behavior, 40, 1081-1088.

Blanchard, R. (2012). Scholarly, clinical, and legal questions concerning hebephilia, with particular reference to sexually violent predator civil commitment proceedings. Journal of the American Academy of Psychiatry and the Law, 40, 157-158.

Blanchard, R. (2013). A dissenting opinion on DSM-5 Pedophilic Disorder [Letter to the Editor].Archives of Sexual Behavior. doi:10.1007/s10508013-01117-x38-5-z.

Bouman, W.P., Bauer, G. R., Richards, C., \& Coleman, E. (2010). World Professional Association for Transgender Health statement on considerations of the role of distress (Criterion D) in the DSM diagnosis of Gender Identity Disorder. International Journal of Transgenderism, 12, 100-106.

Brotto, L. A. (2010a). The DSM diagnostic criteria for Hypoactive Sexual Desire Disorder in women. Archives of Sexual Behavior, 39, 221-239.

Brotto, L. A. (2010b). The DSM diagnostic criteria for Sexual Aversion Disorder. Archives of Sexual Behavior, 39, 271-277. 
Brotto, L. A. (2010c). The DSM criteria for Hypoactive Sexual Desire Disorder in men. Journal of Sexual Medicine, 7, 2015-2030.

Brotto, L. A., Bitzer, J., Laan, E., Leiblum, S., \& Luria, M. (2010). Women's sexual desire and arousal disorders. Journal of Sexual Medicine, 7 , $586-614$.

Brotto, L. A., Graham, C. A., Binik, Y. M., Segraves, R. T., \& Zucker, K. J. (2011). Should sexual desire and arousal disorders in women be merged? A Response to DeRogatis, Clayton, Rosen, Sand, and Pyke (2010) [Letter to the Editor]. Archives of Sexual Behavior, 40, 221-225.

Cantor, J. M. (2012a). Is homosexuality a paraphilia? The evidence for and against. Archives of Sexual Behavior, 40, 237-247.

Cantor, J. M. (2012b). The errors of Karen Franklin's pretextuality. International Journal of Forensic Mental Health, 11, 59-62.

Cohen-Kettenis, P. T., \& Pfäfflin, F. (2010). The DSM diagnostic criteria for Gender Identity Disorder in adolescents and adults. Archives of Sexual Behavior, 39, 499-513.

Corneil, T. A., Eisfeld, J. H., \& Botzer, M. (2010). Proposed changes to diagnoses related to gender identity in the DSM: A World Professional Association for Transgender Health consensus paper regarding the potential impact on access to health care for transgender persons. International Journal of Transgenderism, 12, 107-114.

De Block, A., \& Adriaens, P. R. (2013). Pathologizing sexual deviance: A history. Journal of Sex Research, 50, 276-298.

De Cuypere, G., Knudson, G., \& Bockting, W. (2010). Response of the World Professional Association for Transgender Health to the proposed DSM 5 criteria for Gender Incongruence. International Journal of Transgenderism, 12, 119-123.

DeRogatis, L. R., Clayton, A. H., Rosen, R., Sand, M., Garcia, M., \& Pyke, R. (2010a). Do multiple convergent measures of female sexual dysfunction support sexual desire and arousal disorders as distinct diagnoses? Journal of Sexual Medicine, 7(Suppl. 3), 142143.

DeRogatis, L. R., Clayton, A. H., Rosen, R. C., Sand, M., \& Pyke, R. E. (2011). Should sexual desire and arousal disorders in women be merged? [Letter to the Editor]. Archives of Sexual Behavior, 40, $217-219$.

DeRogatis, L. R., Laan, E., Brauer, M., van Lunsen, R. H. W., Jannini, E. A., Davis, S. R., et al. (2010b). Responses to the proposed DSM-V changes. Journal of Sexual Medicine, 7, 1998-2014.

DeRogatis, L., Rosen, R. C., Goldstein, I., Werneburg, B., KempthorneRawson, J., \& Sand, M. (2012). Characterization of Hypoactive Sexual Desire Disorder(HSDD) in men. Journal of Sexual Medicine, 9, 812-820.

Drescher, J. (2010). Queer diagnoses: Parallels and contrasts in the history of homosexuality, gender variance, and the Diagnostic and Statistical Manual. Archives of Sexual Behavior, 39, 427-460.

Drescher, J. (2013). Controversies in gender diagnoses. LGBT Health, . doi:10.1089/lgbt.2013.1500.

Drescher, J., Cohen-Kettenis, P. T., \& Winter, S. (2012). Minding the body: Situating gender diagnoses in the ICD-11. International Review of Psychiatry, 24, 568-577.

Ehrbar, R. D. (2010). Consensus from differences: Lack of professional consensus on the retention of the Gender Identity Disorder diagnosis. International Journal of Transgenderism, 12, 60-74.

Eliason, M. J. (2010). A new classification system for lesbians: The Dyke Diagnostic Manual. Journal of Lesbian Studies, 14, 401-414.

Fabian, J. M. (2011). Diagnosing and litigating hebephilia in sexually violent predatory civil commitment proceedings. Journal of the American Academy of Psychiatry and the Law, 39, 496-505.

Fedoroff, J. P. (2011). Forensic and diagnostic concerns arising from the proposed DSM-5 criteria for sexual paraphilic disorder. Journal of the American Academy of Psychiatry and the Law, 39, 238-241.

First, M. B. (2010). DSM-5 proposals for paraphilias: Suggestions for reducing false positives related to use of behavior manifestations [Letter to the Editor]. Archives of Sexual Behavior, 39, 1239-1244.
First, M. B. (2011). The inclusion of child pornography in the DSM-5 diagnostic criteria for Pedophilia: Conceptual and practical problems. Journal of the American Academy of Psychiatry and the Law, 39, 250-254.

First, M. B., \& Frances, A. (2008). Issues for DSM-V: Unintended consequences of small changes: The case of paraphilias. American Journal of Psychiatry, 165, 1240-1241.

First, M. B., \& Halon, R. L. (2008). Use of DSM paraphilia diagnoses in sexually violent predator commitment cases. Journal of the American Academy of Psychiatry and the Law, 36, 443-454.

Frances, A., \& First, M. B. (2011a). Hebephilia is not a mental disorder in DSM-IV-TR and should not become one in DSM-5. Journal of the American Academy of Psychiatry and the Law, 39, 78-85.

Frances, A., \& First, M. B. (2011b). Paraphilia NOS, nonconsent: Not ready for the courtroom. Journal of the American Academy of Psychiatry and the Law, 39, 555-561.

Frances, A., \& Wollert, R. (2012). Sexual sadism: Avoiding its misuse in sexually violent predator evaluations. Journal of the American Academy of Psychiatry and the Law, 40, 409-416.

Franklin, K. (2010a). Hebephilia: Quintessence of diagnostic pretextuality. Behavioral Science and the Law, 28, 751-768.

Franklin, K. (2010b). Why the rush to create dubious new sexual disorders? [Letter to the Editor]. Archives of Sexual Behavior, 39, $819-820$.

Franklin, K. (2011). Proposals to add new paraphilias to the Diagnostic and Statistical Manual, Edition 5(DSM-5). Journal of the AmericanAcademy of Psychiatry and the Law, 39, 137.

Fraser, L., Karasic, D., Meyer, W., \& Wylie, K. (2010). Recommendations for revision of the $D S M$ diagnosis of Gender Identity Disorder in adults. International Journal of Transgenderism, 12, 80-85.

Garcia, F. D., \& Thibaut, F. (2010). Sexual addictions. American Journal of Drug and Alcohol Abuse, 36, 254-260.

Gert, B., \& Culver, C. M. (2009). Sex, immorality, and mental disorders. Journal of Medicine and Philosophy, 34, 487-495.

Giles, K. R., \& McCabe, M. P. (2009). Conceptualizing women's sexual function: Linear vs. circular models of sexual response. Journal of Sexual Medicine, 6, 2761-2771.

Giordano, S. (2011). Where Christ did not go: Men, women and Frusculicchi. Gender Identity Disorder: Epistemological and ethical issues relating to the psychiatric diagnosis. Monash Bioethics Review, 29, $1-22$.

Good, P., \& Burstein, J. (2012). Hebephilia and the construction of a fictitious diagnosis. Journal of Nervous and Mental Disease, 200, 492-494.

Graham, C. A. (2010a). The DSM diagnostic criteria for Female Sexual Arousal Disorder. Archives of Sexual Behavior, 39, 240-255.

Graham, C. A. (2010b). The DSM diagnostic criteria for Female Orgasmic Disorder. Archives of Sexual Behavior, 39, 256-270.

Green, R. (2010). Sexual preference for 14-year-olds as a mental disorder: You can't be serious!! [Letter to the Editor]. Archives of Sexual Behavior, 39, 585-586.

Green, J., McGowan, S., Lev, J., Wallbank, R., \& Whittle, S. (2011). Recommendations from the WPATH consensus process for revision of the DSM diagnosis of Gender Identity Disorders: Implications for human rights. International Journal of Transgenderism, 13, 1-4.

Halpern, A. L. (2011). The proposed diagnosis of Hypersexual Disorder for inclusion in DSM-5: Unnecessary and harmful [Letter to the Editor]. Archives of Sexual Behavior, 40, 487-488.

Hames, R., \& Blanchard, R. (2012). Anthropological data regarding the adaptiveness of hebephilia [Letter to the Editor]. Archives of Sexual Behavior, 41, 745-747.

Hames, R., \& Blanchard, R. (2013). Postscript to "anthropological data regarding the adaptiveness of hebephilia" [Letter to the Editor]. Archives of Sexual Behavior. doi:10.1007/s10508-013-0138-5-z.

Hanson, R. K. (2010). Dimensional measurement of sexual deviance. Archives of Sexual Behavior, 39, 401-404. 
Haraldsen, I., Ehrbar, R. D., Gorton, R. N., \& Menvielle, E. (2010). Recommendations for revision of the DSM diagnosis of Gender Identity Disorder in adolescents. International Journal of Transgenderism, 12, 75-79.

Hendrickx, L., Gijs, L., \& Enzlin, P. (2013). Distress, sexual dysfunctions, and DSM: Dialogue at cross purposes? Journal of Sexual Medicine, $10,630-641$.

Hinderliter, A. C. (2010). Disregarding science, clinical utility, and the DSM's definition of mental disorder: The case of Exhibitionism, Voyeurism, and Frotteurism [Letter to the Editor]. Archives of Sexual Behavior, 39, 1235-1237.

Hinderliter, A. C. (2011). Defining paraphilia in DSM-5: Do not disregard grammar. Journal of Sex and Marital Therapy, 37, 17-31.

Hucker, S. J. (2011). Hypoxyphilia. Archives of Sexual Behavior, 40, 13231326.

Janssen, D. F. (2013). Is "pedophilia" a paraphrase of the incest taboo? Apropos: Are the corollaries of taboo offered up as a reason for it? [Letter to the Editor]. Archives of Sexual Behavior. doi:10.1007/s10508-0130131-z.

Johnson, T. W., \& Wassersug, R. J. (2010). Gender Identity Disorder outside the binary: When Gender Identity Disorder-Not Otherwise Specified is not good enough [Letter to the Editor]. Archives of Sexual Behavior, 39, 597-598.

Kafka, M. P. (2010a). The DSM diagnostic criteria for Fetishism. Archives of Sexual Behavior, 39, 357-362.

Kafka, M. P. (2010b). The DSM diagnostic criteria for Paraphilia Not Otherwise Specified. Archives of Sexual Behavior, 39, 373-376.

Kafka, M. P. (2010c). Hypersexual Disorder: A proposed diagnosis for DSM-V. Archives of Sexual Behavior, 39, 377-400.

Kafka, M.P.(2010d)."What is sexual addiction"? A response to Stephen Levine. Journal of Sex and Marital Therapy, 36, 276-281.

Kafka, M. P., \& Krueger, R. B. (2011a). Response to Moser's (2010) critique of Hypersexual Disorder for DSM-5 [Letter to the Editor]. Archives of Sexual Behavior, 40, 231-232.

Kafka, M. P., \& Krueger, R. B. (2011b). Response to Halpern (2011) [Letter to the Editor]. Archives of Sexual Behavior, 40, 489-490.

Kim, E. D., Eardley, I., McCarthy, B. W., Sand, M., Nelson, C., Miner, M. M., et al. (2010). Comments on "Considerations for diagnostic criteria for Erectile Dysfunction in DSM-V". Journal of Sexual Medicine, 7, 661-671.

Knight, R. A. (2010). Is a diagnostic category for Paraphilic Coercive Disorder defensible? Archives of Sexual Behavior, 39, 419-426.

Knudson, G., De Cuypere, G., \& Bockting, W. (2010a). Foreword. International Journal of Transgenderism, 12, 53.

Knudson, G., De Cuypere, G., \& Bockting, W. (2010b). Process toward consensus on recommendations for revision of the DSM diagnoses of Gender Identity Disorders by the World Professional Association for Transgender Health. International Journal of Transgenderism, 12, $54-59$.

Knudson, G., De Cuypere, G., \& Bockting, W. (2010c). Recommendations for revision of the DSM diagnosis of Gender Identity Disorders: Consensus statement of the World Professional Association for Transgender Health. International Journal of Transgenderism, 12, 115-118.

Knudson, G., De Cuypere, G., \& Bockting, W. (2011a). Response of the World Professional Association for Transgender Health to the proposed revision of the diagnosis of Transvestic Fetishism for DSM 5. International Journal of Transgenderism, 13, 5-8.

Knudson, G., De Cuypere, G., \& Bockting, W.(2011b). Second response of the World Professional Association for Transgender Health to the proposed revision of the diagnosis of Transvestic Disorder for DSM 5. International Journal of Transgenderism, 13, 9-12.

Koh, J. (2012). [The history of the concept of gender identity disorder]. Seishin Shinkeigaku Zasshi, 114, 673-680.
Kramer, R. (2011). APA guidelines ignored development of diagnostic criteria for pedohebephilia [Letter to the Editor]. Archives of Sexual Behavior, 40, 233-235.

Krueger, R. B. (2010a). The DSM diagnostic criteria for Sexual Sadism. Archives of Sexual Behavior, 39, 325-345.

Krueger, R. B. (2010b). The DSM diagnostic criteria for Sexual Masochism. Archives of Sexual Behavior, 39, 346-356.

Krueger, R. B. (2011). Critical appraisals of the proposed DSM-5 paraphilic disorders. Journal of the American Academy of Psychiatry and the Law, 39, 237.

Krueger, R. B., \& Kaplan, M. S. (2012). Paraphilic diagnoses in DSM-5. Israeli Journal of Psychiatry and Related Sciences, 49, 248-254.

Laan, E., \& Both, S. (2011). Sexual desire and arousal disorders in women. Advances in Psychosomatic Medicine, 31, 16-34.

Långström, N. (2010). Exhibitionism, Voyeurism, and Frotteurism: Literature review and suggestions for the DSM-V. Archives of Sexual Behavior, 39, 317-324.

Lawrence, A. A. (2010a). Sexual orientation versus age of onset as bases for typologies (subtypes) of Gender Identity Disorder in adolescents and adults. Archives of Sexual Behavior, 39, 514-545.

Lawrence, A. A. (2010b). Proposed revisions to Gender Identity Disorder diagnoses in the DSM-5 [Letter to the Editor]. Archives of Sexual Behavior, 39, 1253-1260.

Lawrence, A. A. (2011). Do some men who desire sex reassignment surgery have a mental disorder? Comment on Meyer-Bahlburg (2010) [Letter to the Editor]. Archives of Sexual Behavior, 40, 651-654.

Levine, S. B. (2010a). Commentary on consideration of diagnostic criteria for Erectile Dysfunction in DSM-V. Journal of Sexual Medicine, 7, 2388-2390.

Levine, S. B. (2010b). What is sexual addiction? Journal of Sex and Marital Therapy, 36, 261-275.

Malón, A. (2012). Pedophilia: A diagnosis in search of a disorder. Archives of Sexual Behavior, 41, 1083-1097.

Marshall, L. E., \& Briken, P. (2010). Assessment, diagnosis, and management of hypersexual disorders. Current Opinion in Psychiatry, $23,570-573$.

Marvin, R. (2010). Proposed DSM-5 revisions to Sexual and Gender Identity Disorder criteria. Virtual Mentor, 12, 673-677.

Meyer-Bahlburg, H. F. L. (2010). From mental disorder to iatrogenic hypogonadism: Dilemmas in conceptualizing gender identity variants as psychiatric conditions. Archives of Sexual Behavior, 39, 461-476.

Meyer-Bahlburg,H.F.L. (2011). Do some men who desire sex reassignment surgery have a mental disorder? Response to Lawrence (2011) [Letter to the Editor]. Archives of Sexual Behavior, 40, 655-657.

Mitchell, K., \& Graham, C. A. (2008). Two challenges for the classification of sexual dysfunction. Journal of Sexual Medicine, 5, 1552-1558.

Moser, C. (2010). Problems with ascertainment [Letter to the Editor]. Archives of Sexual Behavior, 39, 1225-1227.

Moser, C. (2011a). Hypersexual Disorder: Just more muddled thinking [Letter to the Editor]. Archives of Sexual Behavior, 40, 227-229.

Moser, C. (2011b). Yet another paraphilia definition fails [Letter to the Editor]. Archives of Sexual Behavior, 40, 483-485.

Neutze, J., Grundmann, D., Scherner, G., \& Beier, K. M. (2012). Undetected and detected child sexual abuse and child pornography offenders. International Journal of Law and Psychiatry, 35, 168-175.

O'Donohue, W. (2010). A critique of the proposed DSM-V diagnosis of Pedophilia [Letter to the Editor]. Archives of Sexual Behavior, 39, 587-590.

Pfäfflin, F. (2011). Remarks on the history of the terms Identity and Gender Identity. International Journal of Transgenderism, 13, 13-25.

Prentky, R., \& Barbaree, H. (2011). Commentary: Hebephilia-a would-be paraphilia caught in the twilight zone between prepubescence and adulthood. Journal of the American Academy of Psychiatry and the Law, 39, 506-510. 
Quinsey, V.L. (2010). Coercive Paraphilic Disorder. Archives of Sexual Behavior, 39, 405-410.

Quinsey, V. L. (2012). Pragmatic and Darwinian views of the paraphilias. Archives of Sexual Behavior, 41, 217-220.

Rachlin, K., Dhejne, C., \& Brown, G. R. (2010). The future of GID NOS in the DSM 5: Report of the GID NOS Working Group of a consensus process conducted by the World Professional Association for Transgender Health. International Journal of Transgenderism, 12, 86-93.

Reid, R. C., Carpenter, B. N., Hook, J. N., Garos, S., Manning, J. C., Gilliland, R., et al. (2012). Report of findings in a DSM-5 field trial for Hypersexual Disorder. Journal of Sexual Medicine, 9, 28682877.

Rellini, A. H., \& Clifton, J. (2011). Female Orgasmic Disorder. Advances in Psychosomatic Medicine, 31, 35-56.

Richter-Appelt, H., \& Sandberg, D. E. (2010). Should Disorders of Sex Development be an exclusion criterion for Gender Identity Disorder in DSM 5? International Journal of Transgenderism, 12, 94-99.

Rind, B. (2013). Critique of Hames and Blanchard (2012), Clancy (2012), and Ryniker (2012) on hebephilia, anthropological data, and maladaptiveness [Letter to the Editor]. Archives of Sexual Behavior. doi:10. 1007/s10508-013-0132-y.

Rind, B., \& Yuill, R. (2012). Hebephilia as mental disorder? A historical, cross-cultural, sociological, cross-species, non-clinical empirical, and evolutionary review. Archives of Sexual Behavior, 41, 797-829.

Ryniker, D. C. (2012). Hebephilia and male fertility [Letter to the Editor]. Archives of Sexual Behavior, 41, 741-743.

Segraves, R. T. (2010a). Considerations for diagnostic criteria for Erectile Dysfunction in DSM V. Journal of Sexual Medicine, 7, 654-660.

Segraves, R. T. (2010b). Considerations for an evidence based definition of Premature Ejaculation in the DSM-V. Journal of Sexual Medicine, 7, 672-689.

Segraves, R. T. (2010c). Considerations for a better definition of Male Orgasmic Disorder in DSM V. Journal of Sexual Medicine, 7, 690-695.

Segraves, R. T., Balon, R., \& Clayton, A. (2007). Proposal for changes in diagnostic criteria for sexual dysfunctions. Journal of Sexual Medicine, 4, 567-580.

Seto, M.C. (2010). Child pornography use and internet solicitation in the diagnosis of pedophilia [Letter to the Editor]. Archives of Sexual Behavior, 39, 591-593.

Seto, M.C. (2012). Is pedophilia a sexual orientation? Archives of Sexual Behavior, 40, 231-236.

Shindel, A. W., \& Moser, C. A. (2011). Why are the paraphilias mental disorders? Journal of Sexual Medicine, 8, 927-929.

Singy, P. (2010). What's wrong with sex? [Letter to the Editor]. Archives of Sexual Behavior, 39, 1231-1233.

Stern, P. (2010). Paraphilic Coercive Disorder in the DSM: The right diagnosis for the right reason. Archives of Sexual Behavior, 39, 1443-1447.

Stern, P. (2011). Wollert (2011) demonstrates again how ideology taints scientific debate [Letter to the Editor]. Archives of Sexual Behavior, 40, 1099-1100.

Taborda, J. G., \& Michalski-Jaeger, C. A. (2012). Sexual disorders and crime. Current Opinion in Psychiatry, 25, 370-374.

Thornton, D. (2010). Evidence regarding the need for a diagnostic category for a coercive paraphilia. Archives of Sexual Behavior, 39, 411-418.
Tucker, D., \& Brakel, S. J. (2012). DSM-5 paraphilic diagnoses and SVP law [Letter to the Editor]. Archives of Sexual Behavior, 41, 533.

Vale, K., Johnson, T. W., Jansen, M. S., Lawson, B. K., Lieberman, T., Willette, K. H., et al. (2010). The development of standards of care for individuals with a Male-to-Eunuch Gender Identity Disorder. International Journal of Transgenderism, 12, 40-51.

Vance, S. R., Cohen-Kettenis, P. T., Drescher, J., Meyer-Bahlburg, H. F. L., Pfäfflin, F., \& Zucker, K. J. (2010). Opinions about the DSM Gender Identity Disorder diagnosis: Results from an international survey administered to organizations concerned with the welfare of transgender people. International Journal of Transgenderism, 12, $1-14$.

Wakefield, J. C. (2011). DSM-5 proposed diagnostic criteria for sexual paraphilias: Tensions between diagnostic validity and forensic utility. International Journal of Law and Psychiatry, 34, 195-209.

Walters, G. D., Knight, R. A., \& Langstrom, N. (2011). Is hypersexuality dimensional? Evidence for the DSM-5 from general population and clinical samples. Archives of Sexual Behavior, 40, 1309-1321.

Winters, J. (2010). Hypersexual Disorder: A more cautious approach [Letter to the Editor]. Archives of Sexual Behavior, 39, 594-596.

Winters, J., Christoff, K., \& Gorzalka, B. B. (2010). Dysregulated sexuality and high sexual desire: Distinct constructs? Archives of Sexual Behavior, 39, 1029-1043.

Wölfle, R. (2010). [Sexual addiction: Chimera or clinical syndrome? A plea for a clinical conceptualization]. Neuropsychiatrie, 24, 209 216.

Wollert, R. (2011). Paraphilic Coercive Disorder does not belong in the DSM-5 for statistical, historical, conceptual, and practical reasons [Letter to the Editor]. Archives of Sexual Behavior, 40, 1097-1098.

Wollert, R., \& Cramer, E. (2011). Sampling extreme groups invalidates research on the paraphilias: Implications for DSM-5 and sex offender risk assessments. Behavioral Science and the Law, 29, 554-565.

Wright, S. (2010). Depathologizing consensual sexual sadism, sexual masochism, transvestic fetishism, and fetishism [Letter to the Editor]. Archives of Sexual Behavior, 39, 1229-1230.

Wylie, K., Ralph, D., Levin, R. J., Corona, G., \& Perelman, M. A. (2010). Comments on "Considerations for a better definition of Male Orgasmic Disorder in DSM V". Journal of Sexual Medicine, 7, 695-699.

Zonana, H. (2011). Sexual disorders: New and expanded proposals for the DSM-5-do we need them? Journal of the American Academy of Psychiatry and the Law, 39, 245-249.

Zucker, K. J. (2010). The DSM diagnostic criteria for Gender Identity Disorder in children. Archives of Sexual Behavior, 39, 477-498.

Zucker, K. J. (2013, May). Has the DSM-5 (partially) depathologized pedophilic disorder? In K. J. Zucker (Chair), Report from the DSM-5 Sexual and Gender Identity Disorders Work Group. Symposium conducted at the meeting of the American Psychiatric Association, San Francisco, CA.

Zucker, K. J., Cohen-Kettenis, P. T., Drescher, J., Meyer-Bahlburg, H. F. L., Pfäfflin, F., \& Womack, W. M. (2013). Memo Outlining Evidence for Change for Gender Identity Disorder in the DSM-5. Archives of Sexual Behavior. doi:10.1007/s10508-013-0139-4. 